\title{
KEGIATAN LATIHAN GERAK DAN LAGU (JERUK BALI) UNTUK MENINGKATKAN PERKEMBANGAN MOTORIK KASAR PADA ANAK USIA DINI
}

\author{
Oleh: \\ Ni Kadek Nelly Paspiani, S.Pd \\ TK Negeri Pembina Kotabaru, \\ nelly_paspiani@gmail.com
}

\begin{abstract}
Abstrak
Perkembangan motorik kasar anak usia dini sama pentingnya dengan aspek perkembangan yang lain. Apabila anak tidak mampu melakukan gerakan fisik dengan baik akan menumbuhkan rasa tidak percaya diri dan konsep diri negatif dalam melakukan gerakan fisik serta akan mengalami keterbatasan dalam hal melakukan aktivitas sehari-hari. Perkembangan motorik kasar anak akan berkembang dengan baik apabila diberikan stimulus yang mampu mendorong anak untuk bergerak, salah satu cara untuk mengembangkan motorik kasar adalah dengan kegiatan latihan gerak dan lagu. Kegiatan latihan gerak dan lagu dapat mempengaruhi semua bidang aspek perkembangan anak terutama perkembangan motorik kasar anak. Kegiatan latihan gerak dan lagu (jeruk bali) dilakukan untuk mengembangkan motorik kasar pada anak TK Negeri Pembina Kotabaru. Sehingga nantinya mampu membantu perkembangan motorik kasar anak agar tidak kaku, lincah dan anak lebih luwes dalam melakukan kegiatan yang nantinya akan berguna untuk kegiatan sehari-hari.
\end{abstract}

Kata kunci: Perkembangan, motorik kasar, anak usia dini

\begin{abstract}
The development of gross motor skill in the early-aged children is as important as another aspect of development. If children are unable to do physical movement well, it could discourage them, create negative self concept in doing physical movement, and also restrict them in doing their daily activities. Children's gross motor skill will develop well if stimuli which can force them to move are given. One of the ways to develop gross motor skill is through training of "move and sing" exercise. The exercise can affect all aspects of children development, especially the gross motor skill development. The exercise of "move and sing" (jeruk bali) was done to develop the children's gross motor skill to the students of TK Negeri Pembina Kotabaru. Therefore later it is expected to help the development of gross motor skill so that children are not stiff, energetic and more flexible in doing daily activities.
\end{abstract}

Keywords: development, gross motor, early-age children

\section{PENDAHULUAN}

Usia dini merupakan periode awal yang paling penting dan mendasar di sepanjang rentang pertumbuhan dan perkembangan kehidupan manusia, sehingga masa dini sering disebut dengan masa usia emas (golden age). Menurut Trianto (2011: 14) menyatakan bahwa anak usia dini merupakan individu yang berbeda, unik dan memiliki karakteristik tersendiri sesuai dengan tahapan usianya. Masa usia dini (0-6 tahun) merupakan masa keemasan (golden age) dimana stimulasi seluruh aspek perkembangan berperan penting untuk tugas perkembangan selanjutnya.

Pendidikan Anak usia dini (PAUD) merupakan upaya pembinaan dan pengasuhan yang ditujukan kepada anak 
sejak lahir hingga usia 6 tahun. Pendidikan bagi anak usia dini dilakukan melalui pemberian rangsangan pendidikan yang bertujuan untuk membantu pertumbuhan dan perkembangan jasmani dan rohani agar anak memiliki kesiapan dalam memasuki pendidikan lebih lanjut seperti pendidikan sekolah dasar.

Pada usia dini anak memiliki kemampuan untuk belajar yang luar biasa khususnya pada masa kanak-kanak awal. Pada masa usia dini terjadinya kematangan fungsi-fungsi fisik dan psikis yang siap merespon stimulasi (rangsangan) yang diberikan oleh lingkungan. Mengingat usia dini merupakan usia emas maka pada masa itu perkembangan anak harus dioptimalkan. Pengoptimalan aspek perkembangan anak dapat dilakukan salah satunya yaitu perkembangan motorik kasarnya.

Perkembangan motorik kasar merupakan hal yang sangat penting bagi anak usia dini khususnya anak kelompok bermain dan taman kanak-kanak. Untuk mengembangkan motorik kasar pada anak perlu adanya bantuan dan bimbingan dari para pendidik dengan melihat kemampuan yang dimiliki oleh anak dan mampu mengembangkan berbagai jenis kegiatan yang dapat merangsang perkembangan motorik kasar pada anak. Kemampuan melakukan gerakan dan tindakan fisik untuk seorang anak terkait dengan rasa percaya diri dan pembentukan konsep diri.

Gerakan-gerakan motorik kasar ini dipraktekkan oleh anak-anak TK di bawah bimbingan dan pengawasan pendidik/guru, sehingga diharapkan semua aspek perkembangan dapat berkembang secara optimal. Pengembangan motorik kasar sama pentingnya dengan aspek-aspek perkembangan lainnya, karena ketidakmampuan anak melakukan kegiatan fisik akan membuat anak kurang percaya diri, bahkan menimbulkan konsep diri negatif dalam kegiatan fisik. Padahal jika anak dibantu oleh pendidik, besar peluangnya dapat mengatasi ketidakmampuan tersebut dan menjadi lebih percaya diri.
Berdasarkan observasi yang saya lakukan ditempat mengajar di daerah 3T, kegiatan yang berkaitan dengan perkembangan motorik kasar belum dilaksanakan dengan maksimal sehingga mendorong saya untuk membuat kegiatan yang dapat mengembangkan motorik kasar anak agar lebih menarik dan bervariasi yakni kegiatan latihan gerak dan lagu (jeruk bali). Adapun tujuan dari kegiatan ini untuk menemukan cara yang tepat dalam mengajarkan motorik kasar anak, menemukan jenis gerak yang tepat untuk perkembangan motorik kasar dan menemukan pola konsep dasar gerak yang efektif.

\section{Anak Usia Dini}

Anak usia dini adalah anak usia 0 8 tahun, dimana pada usia ini anak mengalami lompatan perkembangan, kecepatan perkembangan yang luar biasa dibanding usia sesudahnya. Pada usia tersebut merupakan periode diletakkannya dasar struktur kepribadian yang dibangun untuk sepanjang hidupnya. Perkembangan fisik dan mental pada usia $0-8$ tahun mengalami kecepatan yang luar biasa.

Masa awal kehidupan anak merupakan masa terpenting dalam rentang kehidupan seorang anak. Pada masa ini, pertumbuhan otak sedang mengalami perkembangan yang sangat pesat (eksplosif), begitupun dengan perkembangan fisiknya. Dengan kata lain, bahwa anak usia dini sedang dalam pertumbuhan dan perkembangan baik fisik maupun mental yang sangat pesat. Selain fisik dan mental, perkembangan fisik/motorik, moral (termasuk kepribadian, watak, dan juga akhlak), sosial emosional, intelektual dan bahasa juga berlangsung sangat pesat. Oleh karena itu, usia dini juga disebut tahun keemasan atau golden age. Montessori (dalam Sujiono, 2010:20) menyatakan bahwa masa golden age merupakan periode sensitif (sensitive periods), selama masa inilah anak secara khusus mudah menerima stimulus-stimulus dari 
lingkungannya. Oleh sebab itu, mengembangkan kemampuan dan potensi yang dimiliki anak, hendaknya dimulai dari pendidikan anak usia dini (PAUD). PAUD bertujuan membimbing dan mengembangkan potensi setiap anak agar dapat berkembang secara optimal sesuai dengan tipe kecerdasan yang dimiliki oleh anak.

Berkaitan tentang PAUD, Trianto (2011:24) menyatakan bahwa pendidikan anak usia dini adalah suatu upaya yang ditunjukan kepada anak sejak lahir sampai pada usia enam tahun yang dilakukan melalui rangsangan pendidikan untuk membantu pertumbuhan dan perkembangan jasmani dan rohani agar anak memiliki kesiapan dalam memasuki pendidikan lebih lanjut. PAUD dapat diselenggarakan melalui jalur pendidikan formal (TK atau bentuk lain yang sederajat), nonformal (kelompok bermain dan tempat penitipan anak) dan informal (pendidikan keluarga dilingkungan anak). PAUD berfungsi membina, menumbuhkan dan mengembangkan seluruh potensi anak usia dini secara optimal sehingga terbentuk perilaku dan kemampuan dasar sesuai dengan tahap perkembangan anak agar memiliki kesiapan untuk memasuki pendidikan selanjutnya.

\section{Perkembangan Motorik Kasar}

Motorik kasar adalah kemampuan gerak tubuh yang menggunakan otot-otot besar, sebagian besar atau seluruh anggota tubuh motorik kasar diperlukan agar anak dapat duduk, menendang, berlari, naik turun tangga dan sebagainya. Sujiono (2007: 13) berpendapat bahwa gerakan motorik kasar adalah kemampuan yang membutuhkan koordinasi sebagian besar bagian tubuh anak. Gerakan motorik kasar melibatkan aktivitas otot-otot besar seperti otot tangan, otot kaki dan seluruh tubuh anak

Gerakan motorik kasar melibatkan aktivitas otot-otot besar seperti otot tangan, otot kaki dan seluruh tubuh anak. Perkembangan motorik kasar anak lebih dulu dari pada motorik halus, misalnya anak akan lebih dulu memegang bendabenda yang ukuran besar daripada ukuran yang kecil. Karena anak belum mampu mengontrol gerakan jari-jari tangannya untuk kemampuan motorik halusnya, seperti meronce, menggunting dan lainlain.

Pengembangan motorik kasar di TK bertujuan untuk memperkenalkan dan melatih gerakan kasar, meningkatkan kemampuan mengelola, mengontrol gerakan tubuh dan koordinasi, serta meningkatkan keterampilan tubuh dan cara hidup sehat, sehingga dapat menunjang pertumbuhan jasmani yang sehat, kuat dan terampil. Pengembangan kemampuan dasar anak dilihat dari kemampuan motoriknya, sehingga guru-guru TK perlu membantu mengembangkan keterampilan motorik anak dalam hal memperkenalkan dan melatih gerakan motorik kasar anak, meningkatkan kemampuan mengelola, mengontrol gerakan tubuh dan koordinasi, serta meningkatkan keterampilan tubuh dan cara hidup sehat sehingga dapat menunjang pertumbuhan jasmani yang kuat, sehat dan terampil. Kompetensi anak TK yang diharapkan dapat dikembangkan guru saat anak memasuki lembaga pra sekolah/TK adalah anak mampu melakukan aktivitas motorik secara terkoordinasi dalam rangka kelenturan dan kesiapan untuk menulis, keseimbangan, dan melatih keberanian .

\section{Gerak dan Lagu}

Gerak menjadi hal yang sangat kreatif bila dipadukan dengan musik yang diinterpretasikan anak menurut caranya masing-masing. Akan tetapi sebelum anak mampu melakukan gerak yang ekspresif, terlebih dahulu ia harus menguasai variasivariasi dari gerakan tubuhnya. Belajar melalui gerakan anak dapat belajar tentang dirinya dan dunianya. Latihan gerak dan lagu adalah bernyanyi dan latihan gerak tubuh yang sangat berhubungan erat, 
karena irama lagu dapat mempengaruhi dan mengendalikan pusat syaraf. Sehingga cara belajar yang baik bagi anak adalah melalui lagu dan gerakannya. Untuk itu pembelajaran melalui gerak dan lagu yang dilakukan sambil bermain akan membantu anak untuk lebih mengembangkan kecerdasannya tidak hanya pada aspek pengembangan seni, bahasa dan fisiknya saja tetapi juga pada pengembangan emosional dan kognitif anak.

Kegiatan gerak dan lagu sangat melekat erat dan tidak dapat dipisahkan terutama dalam memberikan pembelajaran kepada anak usia dini. Pembelajaran gerak dan lagu merupakan sebuah kegiatan dalam bermain sambil belajar dan belajar sambil bermain, aktivitas yang dilakukan melalui gerak dan lagu diharapkan akan menyenangkan anak sekaligus menyentuh perkembangan bahasa, kepekaan akan irama musik, perkembangan motorik, rasa percaya diri, serta keberanian mengambil resiko. Karena itu perlu adanya suatu kegiatan yang dapat melatih para pendidik anak usia dini dalam memberikan perangsangan pada anak melalui gerak dan lagu.

Gerak dan lagu sangat baik diberikan untuk anak usia dini, karena melalui gerak dan lagu anak dirangsang untuk gerakan tubuh, tarian dan olah raga yang berhubungan dengan koordinasi tubuh, keseimbangan, kekuatan, kelincahan dan koordinasi mata dengan tangan dan kaki. Kegiatan latihan gerak dan lagu merupakan kegiatan pembelajaran yang menggunakan media tape, CD dengan tujuan anak dapat meningkat perkembangan menggerakkan tubuhnya sesuai dengan irama dan syair lagu, dapat menari dengan luwes dan lentur.

\section{Implementasi Kegiatan Latihan Gerak dan Lagu}

Kegiatan latihan gerak dan lagu yang saya berikan ditempat mengajar menggunakan lagu anak-anak yang sering didengar yaitu lagu jeruk bali. Pemberian kegiatan gerak dan lagu jeruk bali ini saya berikan terlebih dahulu kepada guru disekolah saya.

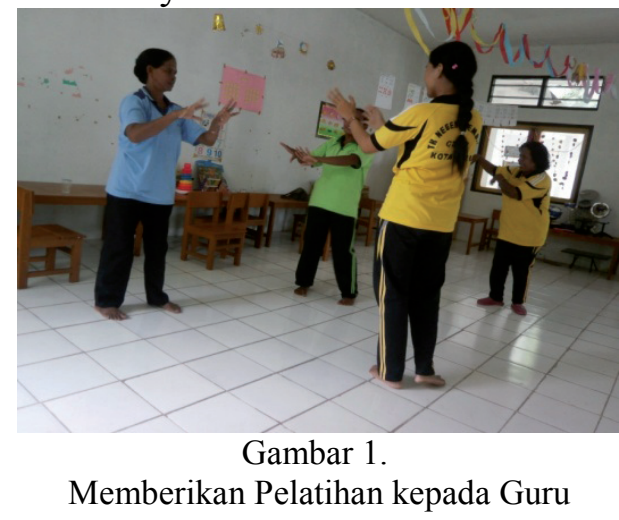

Pada gambar 1, saya memberikan pelatihan kepada guru ragam gerak pada lagu jeruk bali. Pada saat latihan berlangsung saya menggunakan saya laptop dan speaker kecil agar lagu jeruk bali lebih didengar oleh guru. Pelatihan gerak dan lagu jeruk bali berjalan sekitar 2 bulan karena, guru-guru di TK Negeri Pembina baru pertama kali melalukan kegiatan yang berkaitan dengan olah tubuh seperti menari.

Awal pelatihan gerakan yang dilakukan oleh para guru terlihat begitu kaku sehingga saya harus mengulang beberapa kali untuk 1 jenis ragam gerak, akan tetapi para guru tidak menyerah untuk belajar gerak dan lagu jeruk bali. Pelatihan ini saya lakukan setiap hari jumat setelah kegiatan pembelajaran. Setelah beberapa kali latihan guru-guru tampak lebih luwes dan lincah dalam mengikuti gerakan tarian.

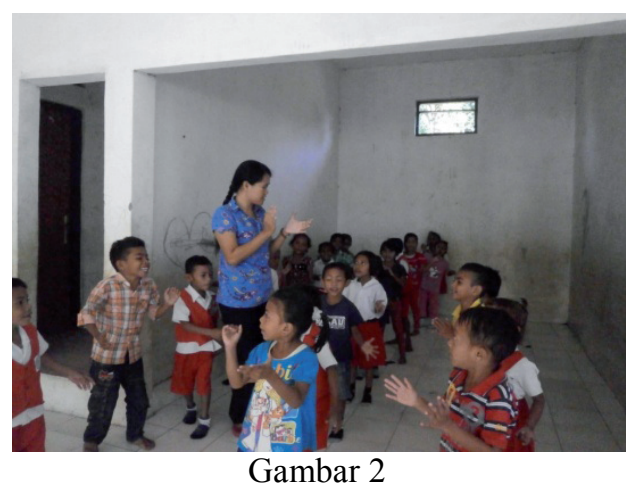

Melatih Anak Bernyanyi Jeruk Bali 
Pada gambar 2, saya mengajarkan anak bernyanyi jeruk bali. Hal ini saya lakukan untuk memudahkan saya mengajarkan anak-anak ragam gerak dalam jeruk bali. Setelah beberapa kali diajarkan anak mulai bisa menyanyikan lagu jeruk bali dengan baik. Selanjutnya, saya mengajarkan anak-anak ragam gerak jeruk bali tanpa diiringi lagu agar anak mampu fokus pada gerakan jeruk bali. Dalam 1 kali pertemuan hanya diberikan 2 jenis ragam gerakan jeruk bali, ini dilakukan agar anak lebih cepat mengerti dan paham gerakan-gerakan pada jeruk bali.

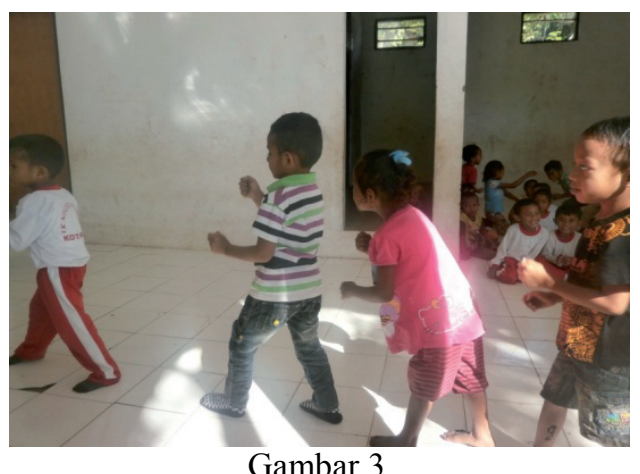

Memberikan Pelatihan kepada Anak Didik

Pada gambar 3, saya bersama guru memberikan latihan gerak dan lagu jeruk bali. Setelah anak menguasai 7 ragam gerakan jeruk bali, saya mengkombinasikan antara gerak dan lagu jeruk bali. Hal pertama yang saya lihat, anak belum begitu lincah dan luwes melakukan gerakan yang diiringi lagu. Banyak anak salah melakukan gerakan bahkan tidak sesuai dengan irama lagu. Walaupun banyak melakukan anak-anak tetap semangat mengikuti kegiatan tersebut.

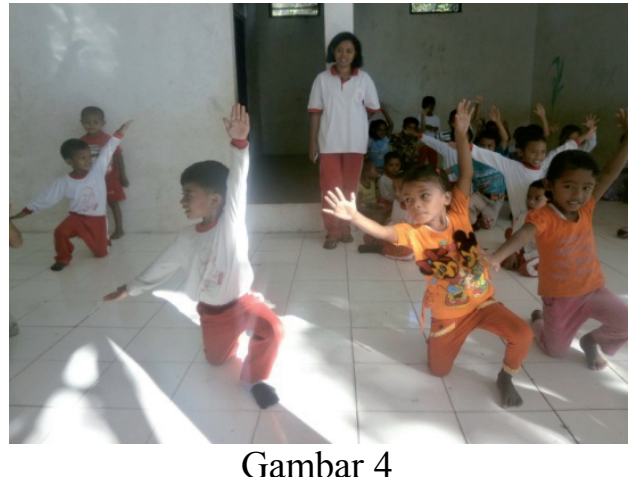

Anak Melakukan Gerak dan Lagu Jeruk Bali

Pada gambar 4, anak-anak masih tetap semangat berlatih jeruk bali. Anak sudah mampu mengikuti irama lagu dan gerak dengan benar walaupun ada beberapa anak yang masih belum bisa. Anak-anak terlihat begitu lincah dan luwes menarikan jeruk bali. Kegiatan latihan ini tidak hanya mengajarkan anak sekedar bisa untuk menari akan tetapi mengajarkan anak bagaimana melakukan koordinasi yang baik antara tangan, kaki, mata dengan benar. Mengingat langkah-langkah dari gerakan, menghafal lagu, dan belajar bekerja sama agar terlihat kompak saat melakukan gerakan jeruk bali.

Gerak dan lagu jeruk bali yang saya ajarkan kepada guru dan anak-anak berhasil dilakukan, walaupun masih ada beberapa gerakan yang belum dilakukan dengan benar. Saat itu, saya juga diberikan tugas oleh UPTD kecamatan Kotabaru untuk mengajarkan gerakan jeruk bali dan juga senam sehat ceria kepada guru-guru TK se-Kecamatan Kotabaru agar guruguru lain juga bisa melakukan gerak dan lagu jeruk bali (gambar 05).

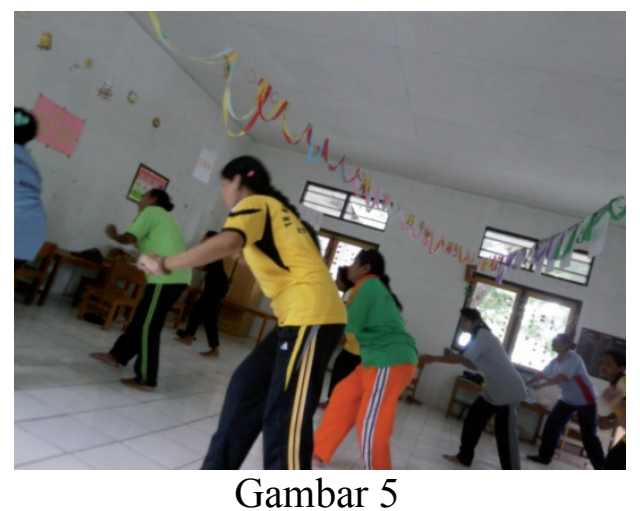


Mengajarkan Guru se-kecamatan Senam

Sehat Ceria dan Jeruk Bali

\section{KESIMPULAN}

Berdasarkan dari kegiatan latihan gerak dan lagu jeruk bali yang saya laksanakan di daerah 3T yaitu di TK Negeri Pembina Kotabaru, maka melalui artikel ini dapat saya simpulkan bahwa terdapat berbagai macam kegiatan yang dapat mengembangkan berbagai perkembangan anak usia dini khususnya perkembangan motorik kasar.

Jenis kegiatan yang dilakukan dapat kita kembangkan dengan inovatif dan kreatif melalui metode dan permainan yang tepat sehingga pembelajaran anak lebih bervariasi tidak menoton itu-itu saja. Jenis kegiatan yang dilakukan pun harus sesuai dengan tingkat kemampuan, minat dan bakat yang dimiliki oleh anak. Kegiatan latihan gerak dan lagu jeruk bali yang saya berikan cocok diterapkan karena kegiatan ini belum pernah dilaksanakan sebelumnya di TK Negeri Pembina Kotabaru.

\section{DAFTAR PUSTAKA}

Trianto. 2011. Desain Pengembangan Pembelajaran Tematik Bagi Anak Usia Dini TK/RA \& Anak Kelas Awal SD/MI. Jakarta: Kencana Prenada Media Group.

Sujiono, dkk. 2007. Metode Pengembangan Kognitif. Jakarta: Universitas Terbuka.

Erlinda, Esti. 2014. Skripsi Pengembangan motorik kasar anak usia dini melalui permainan "melempar dan menangkap bola". Tersedia pada http:// repository.unib.ac.id/8663/2/I,II,II I,II-est.FK (diakses pada tanggal 21 Maret 2016). 